EESTI NSV TEADUSTE AKADEEMIA TOIMETISED 1954. III kd., nr. 3

ИЗВЕСТИЯ АКАДЕМИИ НАУК ЭСТОНСКОИ ССР 1954. ТОМ III, № 3

\title{
NEOLIITILISED JA VARASE METALLIAJA ASULAD EMAJÖE SUUDMEALAL
}

\author{
L. JAANITS, \\ ajalooteaduste kandidaat
}

Neoliitikum ja varane metalliaeg (III-I aastatuhat e. m. a.) on Eesti NSV vanima ajaloo kõige nõrgemini uuritud perioodid. Nii balti-saksa uurijad kui ka kodanlikud eesti arheoloogid osutasid nimetatud perioodidele võrdlemisi vähe tähelepanu. Enamasti juhuslikult kogutud materjale püüdsid nad aga kasutada valitseva ekspluateerijate klassi huvides, moonutades ajaloolist tõde.

Pärast nõukogude korra taaskehtestamist Eestis algas neoliitiliste asulate süstemaatiline uurimine. Alates 1946. aastast on Eesti NSV Teaduste Akadeemia Ajaloo Instituudi poolt teostatud arheoloogilisi kaevamisi tervel real neoliitilistel ja varase metalliaja mälestusmärkidel. Peale selle on NSV Liidu Teaduste Akadeemia Materiaalse Kultuuri Ajaloo Instituut teostanud Narva jõe piirkonna asulate uurimisi. Nende töödega on kogutud rohkearvuliselt uusi materjale seni väga puudulikult tuntud vanima ajaloo perioodide valgustamiseks.

Märkimisväärseid tulemusi on andnud autori poolt teostatud uurimised Emajōe suudmeala asulatel - Akalil ja Kullamäel. Et nendes asulates on elatud väga kaua, umbes kahe aastatuhande kestel, siis pakub nende materjal teatava ülevaate eelnimetatud perioodidest peaaegu terves ulatuses. See asjaolu võimaldab täpsustada eriti neoliitikumi ja varase metalliaja kronoloogiat, millel on suur tähtsus edaspidiste uurimistööde jaoks.

Koos teiste sama aja mälestusmärkidega valgustab Emajõe suudmeala asulate materjal ka mitmeid olulisi momente Eesti NSV territooriumil elanud hõimude materiaalse kultuuri, tootlike jõudude ja ühiskondlike vahekordade arenemises ning eesti rahva etnogeneesi küsimustes. Et $\cdot$ käesolevas kirjutuses ei ole võimalik peatuda kõigil uurimistulemustel, siis piirdume siin lühikese ülevaate andmisega arheoloogilistest materjalidest ja nende dateerimisest.

Emajõe suudmeala kujutab endast käesoleval ajal tasast, soostuva pinnasega madalikku. Mõningates kohtades ulatub turvaskate kuni kuue meetri paksuseni. Geoloogilised andmed tõendavad, et muistse asustuse tekkimise ajal, subboreaalse kliimaperioodi algul, oli suur osa sellest piirkonnast alles soostumata. Maapinna reljeef oli siis märgatavalt mitmekesisem. Madalamate, juba turbaga kattunud alade kõrval leidus rohkesti liivakaid kühme ja künkaid, milledel tukkadena kasvas lodumets. Siinsed jõed ja järved pakkusid häid võimalusi kalastamiseks ning veelindude ja kobraste küttimiseks, metsad ja looduslikud rohumaad aga jahipidamiseks metsloomadele. Seega olid elutingimused muistsetele küttidele ja kalastajatele võrdlemisi soodsad. Seda kinnitab asjaolu, et siinsed asulad on püsinud öige pikka aega ning nende hulk on aja jooksul suurenenud, nähtavasti elanike juurdekasvu tagajärjel. Praegu tuntakse Emajõe suudmealal kaht asulat, kuid on andmeid, et mõnede 


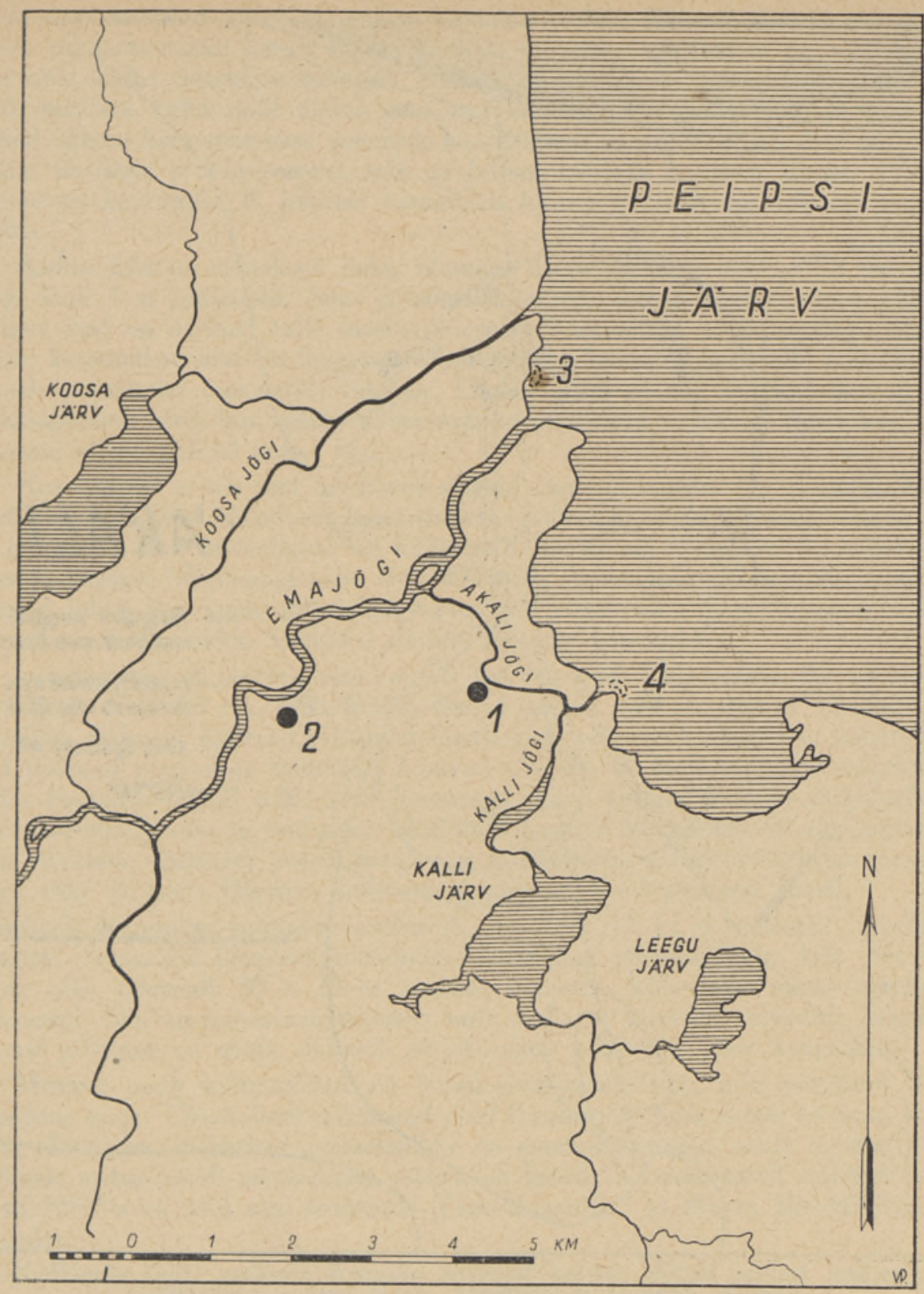

1-Akali asula, 2-Kullamäe asula, 3,4-jörve uhutud leiukohad.

Joon. 1. Emajõe suudmeala skeem.

asulate kultuurkihid on ära uhutud pealetungivate Peipsi vete poolt (joon. 1)'. Peale selle võib siin veel leiduda seni avastamata mälestusmärke.

Akali asula on saanud oma nimetuse Emajõe parempoolse harujõe järgi, mille kaldal ta asetseb. Meie teiste neoliitiliste mälestusmärkidega võrreldes haarab see

1 Oks järve uhutud asulatest on olemasolevate andmete kohaselt olnud küll tunduvalt hilisem, kuuludes nähtavasti XVI-XVII sajandisse. 


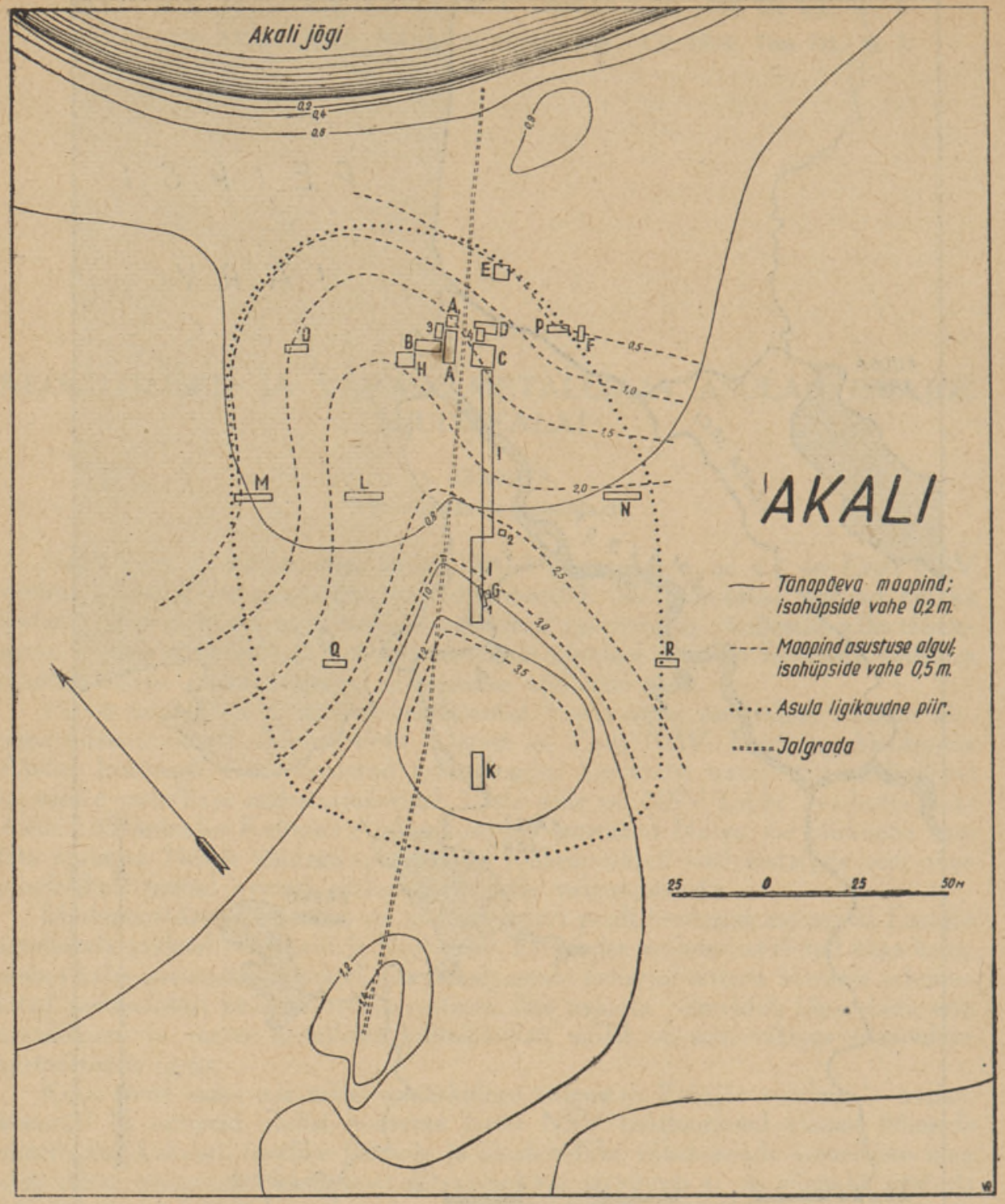

Joon. 2. Akali asula põhiplaan. $A-R, 1-4-$ kaevandid.

asula suhteliselt ulatuslikku territooriumi (joon. 2). Ta pindala võrdub ligikaudu 17000 ruutmeetriga. Sellest on seni läbi uuritud $515 \mathrm{~m}^{2}$, seega ainult $3 \%$. Põhjavee tugeva pealevalgumise tõttu saadi töid teostada ainult väikeste kaevandite abil. Et aga kaevandid tehti asula eri osadesse, siis annavad nad teatava ettekujutuse kogu kultuurkihi iseloomust.

Nagu näitab arheoloogiline materjal, ei ole asula kogu territoorium olnud asustatud üheaegselt. Alguses on elatud jõele kõige lähemal asetsevas piirkonnas, kus kultuurkiht on jäänud tänapäeval rohkem kui $2 \mathrm{~m}$ paksuse turvaskatte alla; kohati, nagu näiteks kaevandites $\mathrm{P}$ ja $\mathrm{E}$, ulatub turba paksus isegi ligemale 3 meetrini. Nendest kaevanditest on saadud ka kõige vanemaid leide. Hiljem, veetaseme tõustes ja pinnase niiskemaks muutudes, on asula järk-järgult nihkunud jõest kauge- 
male, kus maapind kõrgeneb väikse kühmuna. Mida lähemal kühmu tipule, seda õhem on kultuurkihti kattev turvas ja seda hilisemast ajajärgust on pärit ka kultuurkihis leiduv esemeline materjal. Kühmu harjale ei ole turvast veel üldse tekkinud, mistôttu kultuurkiht ulatub seal otse kamara alla. Selle tõttu on asula jäänused kühmu kõrgemas osas peenarde kaevamisega segamini aetud. Just siit on aga leitud üksikuid pronksesemeid, mis on hiljem kahjuks kaduma läinud. Kühmul asetsevast kaevandist $\mathrm{K}$ pärinev keraamika kụulub asula kõige hilisema materjali hulka.

Kultuurkiht on suhteliselt paks, ulatudes asula kesksetes osades $70 \mathrm{~cm}$, kohati isegi kuni $1 \mathrm{~m}$ paksuseni. Söe- ja tahmajäänused, samuti ülalt, turbast allapoole valguv vesi on andnud talle mustja värvuse. Kultuurkiht sisaldab väga tihedasti leide: keraamikat, kivi- ja luuesemeid, merevaiku, loomade ja kalade luid. Siin-seal esineb purustatud teokarpide tükikesi. Luumaterjali ei ole säilinud üksnes asula kühmupoolses osas, kus selleks-nähtavasti on puudunud vajalikud tingimused. Kultuurkihi all on kõikjal puhas liiv.

Kaevamistel ei ole seni avastatud selgeid elamujäänuseid. On võimalik, et elukodadega on olnud ühenduses mõnedes kaevandites esinevad teritatud vaiade otsad ja põhjaliiva sisse süvendatud alt kitsenevad lohukesed. Viimased on erineva suuruse ja kujuga. Mõningaid neist võidi kasutada tagavarade säilitamiseks, osa väiksemaid lohke aga kumerapõhjaliste savinõude hoidmiseks. Sageli asetsevad lohud mitmekaupa lähestikku, kuuludes ilmselt samasse kompleksi.

Leeasemetest on tervena leitud ainult üks, kaevandi I kirdeotsas. See on ovaalne, suurusega $85 \times 60 \mathrm{~cm}$, olles kokku laotud umbes rusikasuurustest kividest. Kultuurkihis leiduvad söeterad, väikesed tuhalaigud, põlenud luukillud ja kohati esinevad põlenud pindadega munakad lubavad oletada, et asula territooriumil on paljudes kohtades tehtud tuld, kuid leeasemed, nagu kergete kodade jäänusedki, on pärastise elutegevuse ja vete poolt hävitatud. Enamik leeasemeid oli aga arvatavasti ilma kivideta, asetsedes paljal maal, sest kultuurkihis leidub töötlemata munakaid väga vähe ja asula lähemas ümbruses puuduvad kivid peaaegu täiesti.

Asula jõepoolses osas, kaevandeis $\mathrm{A}, \mathrm{A}_{1}, \mathrm{~B}, \mathrm{C}, \mathrm{D}, \mathrm{H}$ ja kaevandi I kirdeotsas avastati kultuurkihi ülemises horisondis ulatuslikum põlemisjäänete kiht. See võttis enese alla vähemalt $30 \times 20 \mathrm{~m}$ suuruse maa-ala, küündides mitme sentimeetri paksuseni. Siin on nähtavasti tegemist seda asulaosa tabanud tulekahju jälgedega. Pärast põlemist on asula südamik järjekordselt nihkunud jõest kaugemale.

Mitmelt poolt kultuurkihist on leitud inimkolju tükke, mis mõnikord asusid pesadena koos. Tõenäoliselt pärinevad need fragmendid juba varem hävinud haudadest, tõendades, et surnud asulaelanikke on maetud samasse, asula territooriumile. Mitmest metsavööndi neoliitilisest asulast on leitud ka puutumatult säilinud haudu. Eesti NSV-s on neid seni avastatud Tamula asulas ${ }^{2}$ ja Narva lähedal Riigiküla I asulas.

Kullamäe asula paikneb Emajõe paremal kaldal, Akali asulast umbes $2 \mathrm{~km}$ lääne pool. Siin toimetati kaevamisi aastail 1951-1952, millal väiksemate kaevandite kaupa uuriti läbi $224 \mathrm{~m}^{2}$ suurune pindala. Ulatuselt on Kullamäe asula Akalist mõnevõrra väiksem, hõlmates ümmarguselt 10000 -ruutmeetrilise territooriumi (joon. 3). Looduslikult asendilt sarnaneb ta Akaliga. Siingi on tegemist ümbritsevast rabast veidi kõrgemale küündiva liivakühmuga, kusjuures asulapiirkond on järk-järgult nihkunud kühmu nõlva mööda ülespoole, jõudes viimaks kühmu tipule. Kullamäe eripärasuseks, võrreldes metsavööndi teiste neoliitiliste asulatega, on aga asjaolu, et ta ei asetsenud vahetult vee ääres. Praegu jääb asula äär

2 Л. Я н итс, Поздненеолитические могильники в Әстонской ССР. Краткие сообщения Ннститута нстории материальной культуры АН CCCP, вып. XLII, M., 1952. стр. 59-62. 


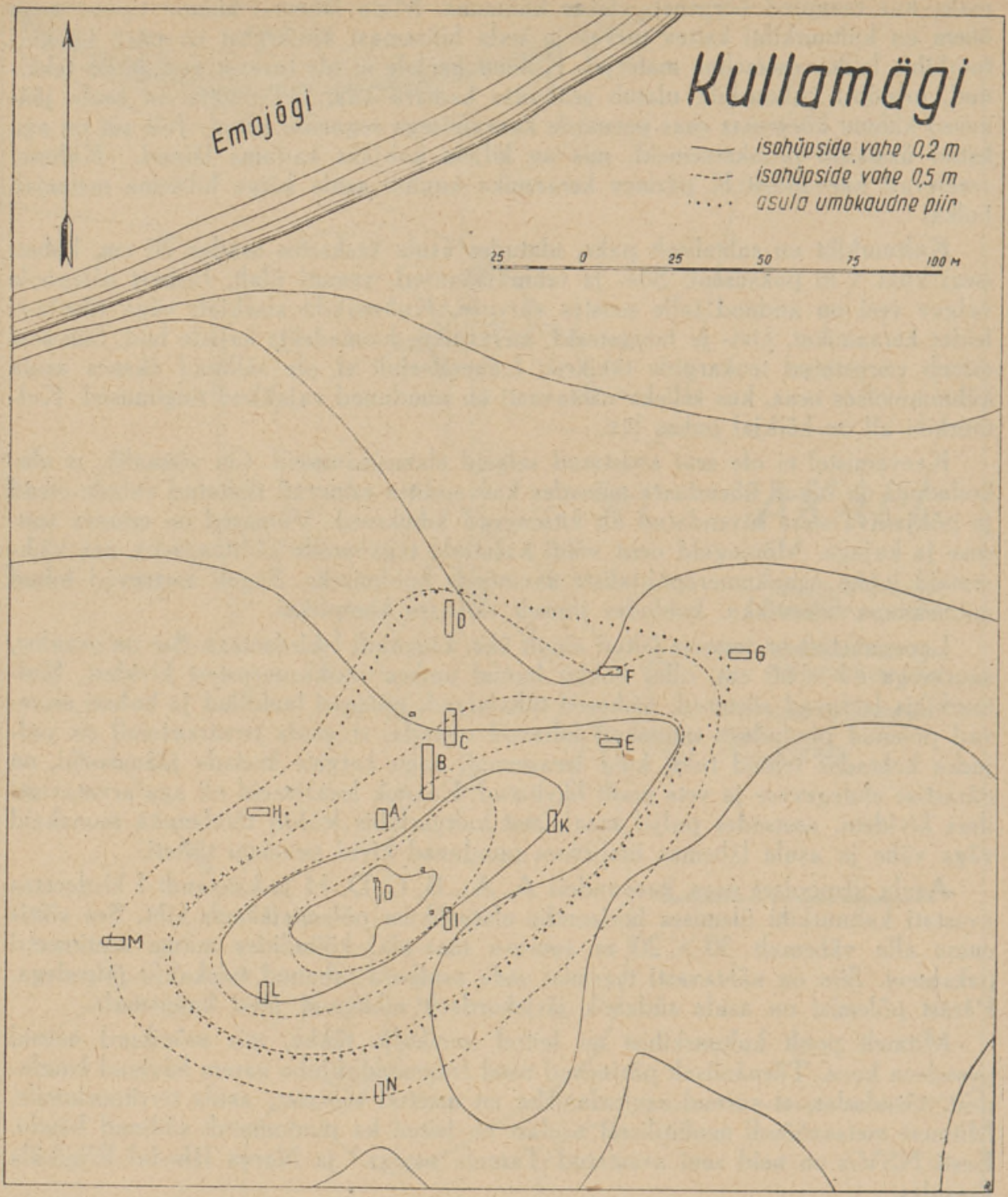

Joon. 3. Kullamäe asula pōhiplaan. A-O - kaevandid.

Emajõest vähemalt $120 \mathrm{~m}$ kaugusele ja vastavalt geoloogilistele andmetele ei ole Emajōe säng varemgi olnud Kullamäele lähemal ${ }^{3}$.

Kultuurkiht asetseb liival. Kühmu jõepoolsel nõlval on kultuurkiht hiljem kattunud turbaga, kuna kühmu kõrgemas osas, kuhu turvast ei ole tekkinud, asetsevad asula jäänused otse kamara all. Kultuurkiht ei ületa paksuselt $50-60 \mathrm{~cm}$ ning sisaldab leide (peamiselt keraamikat ja kiviesemeid) ja põlemisjäänuseid tunduvalt hõredamini kui Akalis. Luumaterjali ei ole siin üldse säilinud, peale mõnede põlenud luukildude. Seni ei ole leitud jälgi elamutest ja leeasemetest, kui mitte

3 Eesti NSV Teaduste Akadeemia tegevliikme K. Orviku poolt toimetatud uurimiste andmeil. 
arvestada üksikuid vaiaotsi ja mõningaid väikesi põhjaliiva süvendatud lohukesi, mis sarnanevad lohukestega Akali asulas.

Kullamäel on asustus alanud mõnevõrra hiljem kui Akalis ja on teataval perioodil nähtavasti mõneks ajaks katkenud. Siiski on mõlemad asulaci püsinud paralleelselt öige pika aja kestel. Kuna Akali ja Kullamäe inventar, eriti keraamika, osutab suurt sarnasust, siis avaneb võimalus kummagi asula materjali leiusuhteid omavahel stratigraafiliselt võrrelda ja sel teel saada kindlamat tuge relatiivsele kronoloogiale.

Emajōe suudmeala asulate inventaris on kõige arvukamalt esindatud keraamika, mida on leitud Akalist ligi 27000 kildu ja Kullamäelt üle 5000 killu. Kiviesemeid ja nende katkendeid on saadud vastavalt üle 1500 ja ligi 300 eksemplari. Peaaegu kolm neljandikku kiviesemete koguarvust moodustavad tulekiviesemed. Rohkesti esineb asulates ka töötlemisjäätmetena tekkinud väikesi tulekivikilde, kuna aga selle toormaterjali vähegi suuremaid tükke tuleb ette väga harva. Seega on tulekivi olnud asulaelanikele kättesaadav ainult väiksemate tükkidena, mida on kasutatud pisikeste esemete, nagu noole- ja heiteodaotste, kõõvitsate, noakeste jne. valmistamisel. Suuremad riistad, sealhulgas kirved ja talvad, on tehtud mitmesugustest kristallilistest kiviliikidest, võrdlemisi sagedasti kiltkivist. Luust ja sarvest esemeid, enamasti katkendlikul kujul, on leitud 280 eksemplari. Luuriistade vähesus on tingitud selle materjali halvemast säilivusest, mistõttu nad Kullamäel ja Akali asula jõest kaugemas osas on peaaegu täiesti hävinenud. Kahtlemata on töö- ja tarberiistade materjalina rohkesti kasutatud ka puitu, kuid peale mõne vaiaotsa, männikoorest võrgukäba ja kasetohurullikese ei ole puitesemetest säilinud mingeid jäänuseid. Jäljetult on hävinenud ka muu orgaaniline materjal. Óksikud Akali asulast leitud pronksesemed on hiljem kaduma läinud.

Seega on vaadeldavate asulate inventar säilinud küllaltki puudulikult. Hoolimata lünkadest annab esemeline materjal siiski teatava ettekujutuse elanikkonna peamistest tootmisaladest ja asulates tehtud tähtsamatest töödest. Lisaks sellele heidab ta mõningat valgust ka siinsete küttide ja kalastajate uskumustele.

Järgnevalt käsitleme lühidalt olulisemat esemelist materjali. Seejuures alustame keraamikast, arvestades tõsiasja, et keraamika on muutunud märgatavalt kiiremini kui mistahes muud töö- ja tarberiistad. Et keraamika on ühtlasi kõige massilisemalt esinevaks materjaliliigiks, siis/tuleb teda pidada kõige kindlamaks aluseks suhteli. sele kronoloogiale.

Akali ja Kullamäe keraamika on õige mitmekesine, jagunedes viide üksteisest selgesti erinevasse rühma: 1) kammkeraamika eelaste, 2) kammkeraamika, 3) tekstiilkeraamika, 4) nöörkeraamika ja 5) varase metalliaja keraamika. Kasutades stratigraafilist meetodit, on võimalik kindlaks teha nimetatud keraamikarühmade kronoloogilisi suhteid, jälgida nii keraamika kohalikku arenemist kui ka uute keraamikaliikide ilmumist asulatesse paari aastatuhande jooksul.

Kammkeraamika eelastet tuleb pidada vanimaks seni teada olevaks keraamikaliigiks Eesti NSV territooriumil. Emajõe suudmealal leiti teda ainult Akali asulast. See keraamika on üsna primitiivne (joon. 4, 1-3). Nõude valmistamiseks kasutatud savisse on segatud rohkesti teokarpide purdu. Põletus on nõrk. Nõud on omanud lihtsat, kumerapõhjalist, enamasti pajataolist kuju, suu laiusega umbes $15-45 \mathrm{~cm}$. Esineb ka üksikuid kilde lamedatest liudadest, mille põhi on siiski olnud kumer. Ornament on napp, otsekui alles välja kujunemata. Ilustustena on savinõude välispindadele vajutatud väikesi korratuid lohukesi, sälke, soonekesi, harva ka kammitaolise stambi jälgi. Suur osa savinõudest on olnud täiesti ilustamata.

Eesti NSV territooriumil tuntakse samasugust keraamikat veel ainult Riigiküla I ja III asulast ${ }^{4}$. Lounapoolsest Ida-Baltikumist talle vasteid ei tunta. Mõningaid sarnasusjooni võib aga konstateerida selle keraamikaliigi ja Leningradi oblasti,

4 Leitud ajalooteaduste kandidaadi N. N. Gurina poolt toimetatud kaevamistel aastail $1951-1953$. 


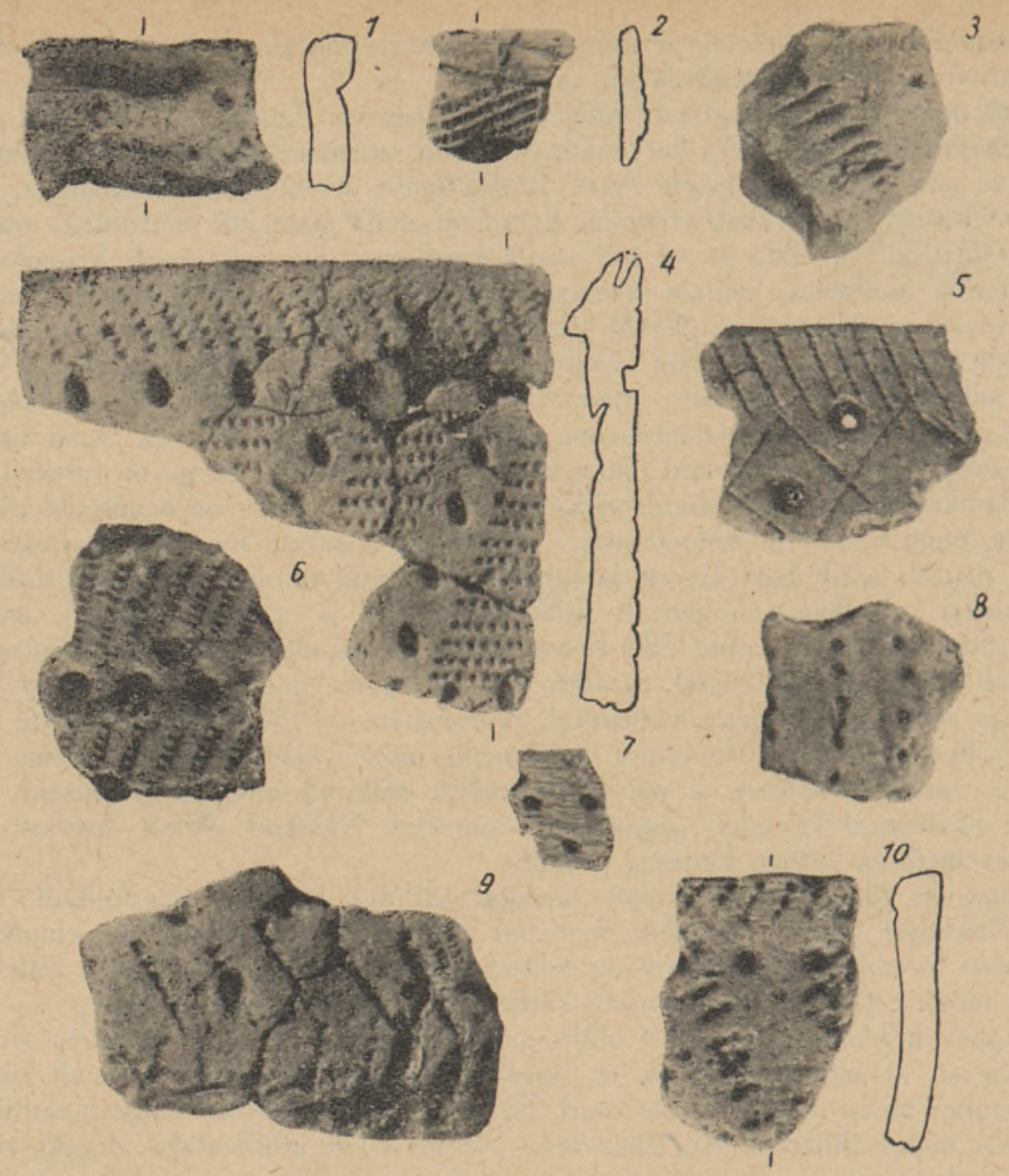

Joon. 4. Keraamikat Akali ja Kullamäe asulatest.

Karjala-Soome NSV ja Soome neoliitilistes asulates esineva nn. Sperringsi tüüpi keraamika vahel. Viimane on neil aladel vanimaks seni teada olevaks keraamikatüübiks, mis on eelnenud tüüpilisele kammkeraamikale ${ }^{5}$. Tõenäoliselt kujutabki Akali ja Riigiküla asulate vanim keraamika enesest Sperringsi tüüpi keraamika lõunapoolset varianti. Ka selle keraamika kujus ja ornamendis leidub mõningaid elemente, mida hiljem arendatakse edasi tüüpilises kammkeraamikas. Sellest hoolimata ei ilmne Akali asulas eneses pidevat üleminekut siinselt kammkeraamika eelastmelt kammkeraamikale. Kuidas kõnesolev keraamika on tekkinud ja kas talle on eelnenud mõni veelgi vanem kohalik keraamikatüüp, on senini selgitamata.

Kammkeraamika moodustab ülekaaluka osa Akali leiumaterjalist, arvukalt leidub seda ka Kullamäel. Stratigraafiliste andmete alusel võib Emajõe suudmeala kammkeraamika arenemises jälgida kaht peamist järku. Mõlemale neist esineb vasteid paljudes teistes Eesti ja Läti ala neoliitilistes asulates.

Kammkeraamika varasel arengujärgul on tegemist tüüpilise kammkeraamikaga (joon. 4, 4-6). Viimane on valmistatud savist, millesse on segatud kivipurdu.

$f^{5}$ Н. Н. Гурин а, Поселения эпохи неолита и раннего металла на северном побережье Онежского озера. Материалы и исследования по археологии СССР, 20. M.-Л. 1951, стр. 80 и сл. - А. Е u r o p a e u s- $\AA$ у г ä рӓ ä, Die relative Chronologie der steinzeitlichen Keramik in Finnland I. Acta Archaeologica, I. København 1930, S. 171 ff. 
Põletus on võrdlemisi tugev. Nõud on kõik pajataolise kujuga, kuid mitmesuguse suurusega. Mahukamate nõude suu läbimõõt on ulatunud poole meetrini. Ilustustena esineb peamiselt kammtempli jälgi ja nende kõrval ka lohukesi. Ornament on peale kantud väga täpselt ja korralikult. Ornamenti iseloomustab vööndiline paigutus ja tihti esinevad geomeetrilised kujundid: kammivajutistest moodustatud rombid, kolmnurgad ja siksakjooned. Ilustused on horisontaalsete vöönditena katnud savinõu kogu välispinda.

Akali asulas on tüüpiline kammkeraamika vahetult järgnenud siinsele kammkeraamika eelastmele. Ometi ei ole ta siin viimasest välja kujunenud, sest erinevus nende vahel on liiga järsk. Akali tüüpilisele kammkeraamikale, eriti ta vanimale osale, leidub kõige lähedasemaid paralleele Laadoga järvest loodepoolsetel aladel, Karjala-Soome NSV edelaosa, Leningradi oblasti loodeosa ja Kagu-Soome asulates, kus vastavat keraamikat esineb väga rohkesti ja kus see on arengulises seoses kohaliku Sperringsi tüüpi keraamikaga ${ }^{6}$. Tundub võimalikuna, et nimetatud piirkonnast on tüüpiline kammkeraamika levinud ka Eesti ja Läti territooriumile, kus on jätkunud ta kohalik edasiarenemine. Selle arengu tulemusena on tekkinud hiline kammkeraamika (joon. 4, 7-10). Uleminek tüüpiliselt kammkeraamikalt hilisele kammkeraamikale on toimunud pidevalt, seda võib jälgida Emajõe suudmeala asulate materjalide alusel. Nõude kuju ja suurus on jäänud üldiselt endiseks, muutused on toimunud peamiselt savi koostises ja ornamentikas. Hiline kammkerazmika on tehtud enamasti peenema koostisega materjalidest. Mõnikord on savisse nähtavasti segatud mingeid orgaanilisi aineid, mis põlemisel on hävinud. Selle tagajärjel on savinõutükid muutunud poorsemaks. Ornamendi vööndiline struktuur on nüüd lagunemas. Ornament on peale kantud hooletult, puudub endine korralikkus ja täpsus. Ilustustena on kammivajutiste kõrval üha suuremal määral kasutatud väikesi lohukesi, aga ka soonekujulisi jm. sissevajutisi. Tihti on savinõude alaosad jäețd ornamenteerimata. Kammkeraamika hilise arengujärgu lõpul hakkab esinema savinõude pindade riipimist. Tuleb ette ka üksikuid lameda põhjaga nõusid.

Nöörkeraamika on Emajõe suudmeala asulatesse ilmunud hilise kammkeraamika lõppjärgul. Varase nöörkeraamika materjaliks on peent liiva sisaldav savi ja ta on hästi põletatud. Nõud on olnud kitsa lameda põhjaga ja veidi nõgusa kaelaosaga. Ilustistena leidub kaelal kas teravalt sissekriimustatud põiksoonekeste ridu (nn. kuuseoks-ornament) või nöörivajutisi (joon. 5, 1-2). Seega on nöörkeraamika täiesti erinev neile asulatele omasest kammkeraamikast. Kuna varajast nöörkeraamikat esineb asulates hilise kammkeraamika leidude seas vaid väheste kildudena, siis ei saa seda pidada kohapeal valmistatuks. Täpselt samasugust nöörkeraamikat on leitud aga Ida-Baltimaade vanimatelt karjakasvatajatelt hõimudelt, $\mathrm{nn}$. sõjakirveste kultuuri kalmistutes ${ }^{7}$. Nöörkeraamika sattumine vaadeldavatesse asulatesse tõendab seega suhtlemist asulaelanike ja sõjakirveste kultuuri hõimude vahel.

Umbes samal ajal kui on alanud nöörkeraamika ilmumine Emajõe suudmeala asulatesse, või veidi hiljem, on siin hakanud esinema ka tekstiilkeraamika hulka kuuluvaid savinõusid. Neil on tihti olnud peaaegu ümar kuju lamenduva põhjaga ja madala, veidi väljapoole hoiduva suuäärisega. Nõude välispinda on katnud jämeda tekstiilkoe jäljed, kuna suuäärist on ilustanud peene kammtempli vajutised (joon. 5, 3). Samalaadne nôutüüp oli sellel perioodil levinud mitmel pool Eesti NSV territooriumist ida pool metsavööndis, näiteks Volga ülemjooksu aladel ja

6 A. Europaeus-Äyrä pää, Die relative Chronologie der steinzeitlichen Keramik in Finnland I, S. 179 ff., Abb. 42-63.

7 X. А. Моор а, Памятники позднего неолита и ранней эпохи металла в Прибалтике. Краткие сообщения Института истории материальной культуры АН СССР, вып. XLVIII, М. 1952, стр. 8, рис. 3. - Л. Я н и тс, Поздненеолитические могнльннки в Эстонской ССР, стр. 53, 55, 57, рнс, 15:1, 5. 
Msta jõe pïrkonnas ${ }^{8}$. Kuigi Kullamäel ja Akalis on tekstiilkeraamika üldiselt kohaliku päritoluga, tuleb ta tarvituselevõtmist seletada idapoolsete ühendustega.

Aja jooksul on kammkeraamika tarvituselt kadunud. Asulates on hakanud nüüd massiliselt levima hiline nöörkeraamika, mille kõrval on tarvitusel püsinud ka tekstiilkeraamika. Mõlemat keraamikaliiki on toodetud koos, samade tegijate poolt. Seetôttu on neil ühesugune savikoostis ja nad on ka vormilt muutunud teineteisele lähedasteks. Hilisele nöörkeraamikale (joon. $5,5,6$ ) on iseloomulik lame põhi ja lai, tugevasti väljapoole ulatuv serv, mille väliskant on tihti ilustatud väikeste täke-

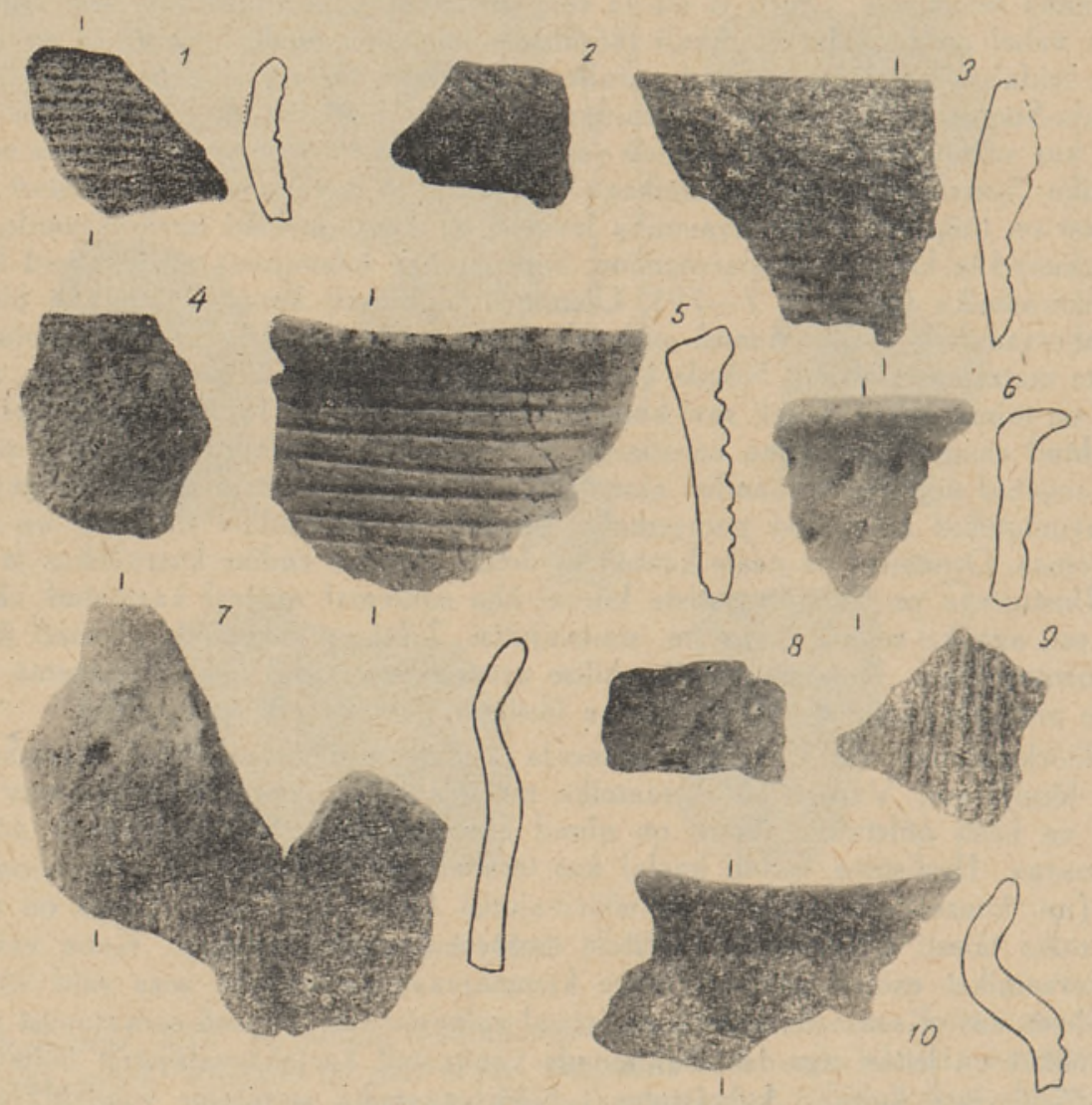

Joon. 5. Keraamikat Akali ja Kullamäe asulatest.

tega. Nõu ülaosa on ornamenteeritud vahel nöörijälgedega, sagedamini aga horisontaalselt ümber nõu kulgevate soontega. Viimaste asemel esineb mõnel nõul pisikesi lohukesi. Nõude alumised osad on kaetud riipimisjälgedega. Tihti leidub hilise nöörkeraamika kildudel peeni, teravalt sissekriimustatud kõverjoonekesi. Neid tuleb ette ka tekstiilijälgedega savinõudel (joon. 5, 4).

Nii on vaadeldavates asulates tekkinud uut tüüpi keraamika, milles peaosa on etendanud nöör- ja tekstiilkeraamika elemendid, kuna kammkeraamikast on säili-

8 П. Н. Т ретьяков, К истории племен Верхнего Поволжья в первом тысячелетии н. Э. Материалы и исследования по археологии СССР, 5, М.-Л., 1941, стр. 15 и сл. - Н. Н. Гурин а, Результаты археологического обследования среднего течения реки Мсты. Советская археология, XIII, М.-Л. 1950, стр. 297 и сл. М. Е. Фосс, Древнейшая история Севера европейской части СССР. Материалы и исследования по археологии СССР, 29, М. 1952, стр. 189 и сл., рис. 99. 

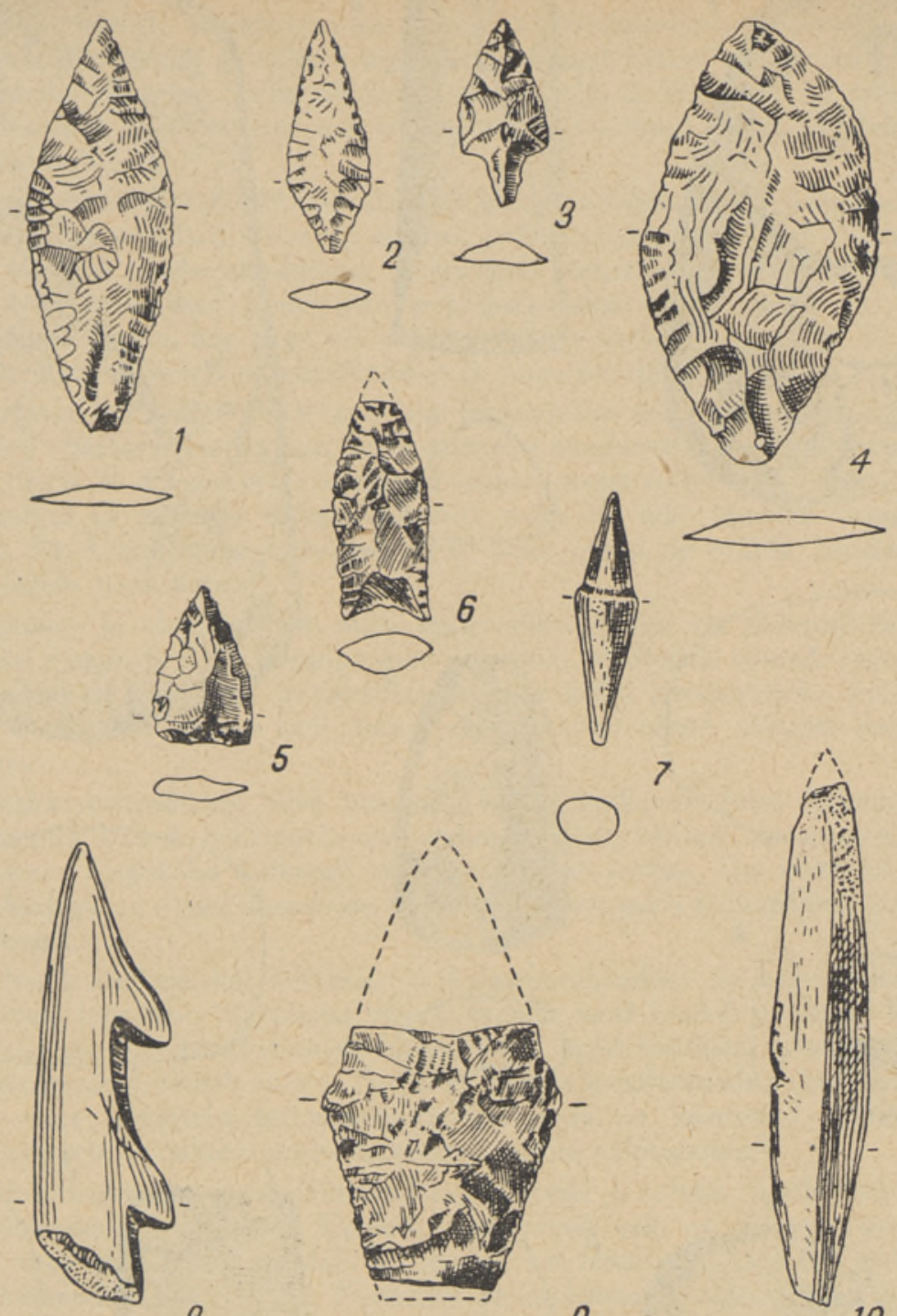

5
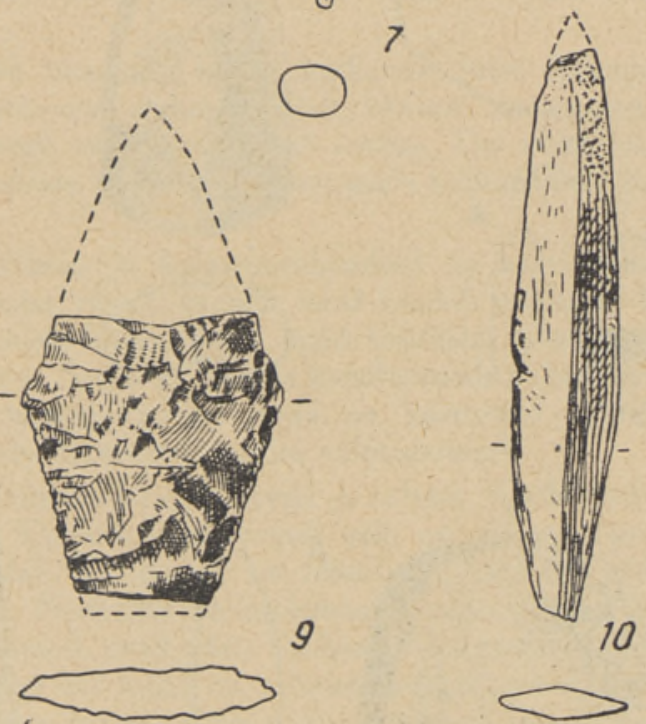

Joon. 6. Küttimis- ja kalastusriistu Akali ja Kullamäe asulatest.

nud mõnede nõude ornamendis ainult teatavaid reministsentse. Selle keraamika edasiarenemine on viinud varase metalliaja keraamika kujunemisele. Viimasel kaovad järjest neoliitilistele savinõudele iseloomulikud jooned. Varase metalliaja keraamika (joon. 5, 7-10) on valmistatud jämeda kivipurruga segatud savist ja on juba õige tugevasti põletatud. Iseloomulikuks nõutüübiks on lamedapõhjaline pott sirge või kergelt profileeritud kaelaga. Poti alumine osa on tihti tugevasti riibitud või kaetud jämedate tekstiilijälgedega. Ornamendina esineb vahel lohukesi ja kammtemplit meenutava stambi jälgi. See keraamika on õige lähedane Eesti NSV territooriumi pronksiaja lõpu ja varase rauaaja muististe, kindlustatud asulate ja 

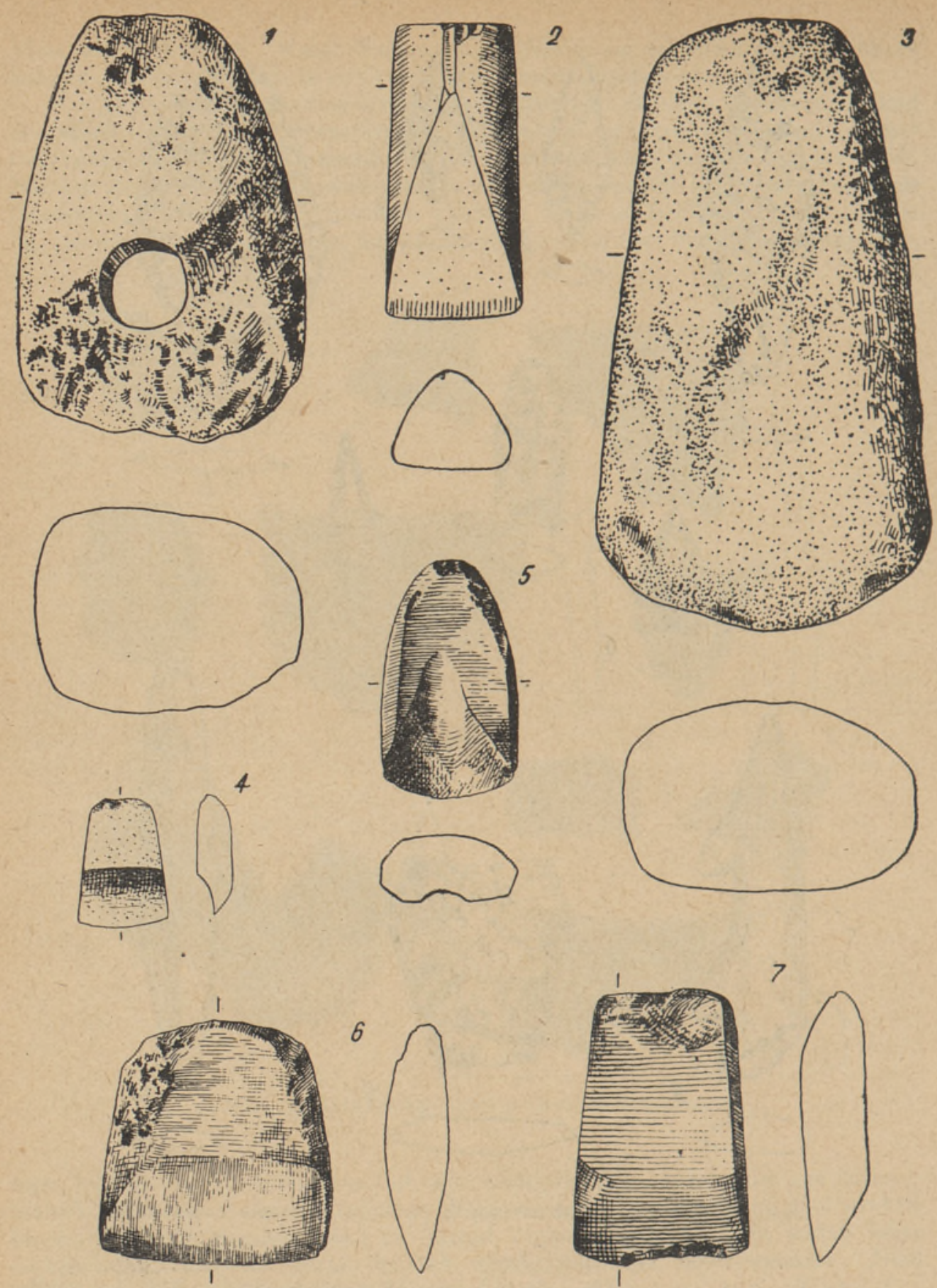

Joon. 7. Kivikirveid ja -talbu Akali ja Kullamäe asulatest.

kivikirstkalmete keraamikale. Akalis ja Kullamäel on see keraamikaliik kõige hilisem, kuuludes nende asulate lõpp-perioodi ${ }^{9}$.

9 Mõlemas asulas leidub küll ka üksikuid veelgi hilisemaid savinõutükke, mis pärinevad I aastatuhande teisest poolest ja II aastatuhande algusest m. a. j., kuid neid ei saa enam ühendada pideva asustusega. 
Meie neoliitiliste asulate elanike peamisteks tootmisvahenditeks on olnud küttimis- ja kalastusriistad. Arvuliselt moodustavad need riistad asulate inventaris siiski üsna tagasihoidliku osa. Selle põhjuseks on asjaolu, et neid kasutati peamiselt väljaspool asulaid, mistõttu suur osa purunenud ja kaotatud eksemplaridest ei sattunud kultuurkihti.

Kõige rohkem esineb küttimisvahendite hulgas nooleotsi, mida koos katkenditega on leitud 92 eksemplari. Neist on enamik valmistatud tulekivist, 7 eksemplari aga luust. Tulekivist nooleotste hulgas domineerib teravovaalne-rombiline tüüp, mis mõnikord on varustatud järsult kitseneva rootsuosaga (joon. 6,1-3); esineb ka väikesi kolmnurkseid, kas sirge või nõgusa alusega nooleotsi (joon. $6,5,6$ ). Luust nooleotste hulgas esineb pajulehekujulist ja koonilist tüüpi (joon. 6, 7, 10).

Odaotstest on leitud ainult ühe laia lehekujulise tulekivist eksemplari katkend Kullamäelt. Samasuguse kujuga, kuid eelmisest tunduvalt väiksemad on neli heiteodaotsa (joon. 6,4). Seevastu kuuluvad teistsugusesse tüüpi kaks heiteodaotsa katkendit, millel on mõlemal külgserval terav nukk ja mis lõpevad sirge alusega (joon. 6,9). Luust heiteodaotsi on leitud kaks. Need on tüübilt lähedased pajulehekujulistele nooleotstele.

Harpuuni- ja ahinguotstest, mille materjaliks oli luu, on säilinud vaid väikesi katkendeid (joon. 6, 8). Harpuuniotsad on olnud võrdlemisi suured, tugevate, ühel serval asetsevate kiskudega ja päraotsas auguga nööri kinnitamiseks. Neid on saadud 12 eksemplari. Ainus seni leitud ahinguots on olnud väikeste kahepoolsete kiskudega.

Ōngitsemisvahenditena tuleb nimetada kolme katkendit luust liitõngedest, mis on koosnenud kahest kokkuseotavast osast. Võrkpüüniste kasutamist tõendab männikoorest võrgukäba katkendi esinemine Akali asulas. On võimalik, et kalapüügivõrkudega on olnud ühenduses ka mitmed sama asula kultuurkihist leitud kasetohurullikesed.

Tunduvalt rohkem kui küttimis- ja kalastusvahendeid on kaevamistel saadud mitmesuguste toorainete töötlemise riistu; enamik neist kuulub puidu ja loomanahkade töötlemisel kasutatud esemete hulka, kuna muid tööriistui, nagu luu- ja kivitöötlemisvahendeid, esineb vähem. Seega on puit ja metsloomade nahad olnud asulaelanikele väga tähtsateks tarbematerjalideks, mida on kasutatud laialdaselt elamute, kehakatete ja mitmesuguste tootmisvahendite valmistamisel.

Puidutöötlemisel on etendanud olulist osa kirved ja talvad. Kivikirved on kujult lihtsad, ümardatud vormidega. Enamik neist, arvult neli, on silmata (joon. 7, 3). Neid on varretatud sidumise abil. Kullamäelt on leitud aga ka kaks silmaga töökirveste katkendit (joon. 7,1 ). Kivitalbu on mõlemast asulast kokku saadud üle poolesaja. Need on üldiselt väikesed, osalt päris pisikesed eksemplarid mitmesuguse kujuga (joon. 7, 6, 7). Tunduv osa talbu on valmistatud kiltkivist. Viimaste hulgas esineb ka mõningaid nn. vene-karjala tüüpi talbu (joon. 7,2), milledega sarnaseid on rohkesti leitud Karjala-Soome NSV territooriumi neoliitilistest asulatest. Erivormidena tuleb nimetada nelja õõsteralist talba (joon. 7,5 ) ja kuut küüstalba (joon. 7, 4). Neid on eriti tarvitatud puust õõnesnõude valmistamisel.

Kivitalbade kõrval leidub asulate inventaris ka sarvest talbu (leitud 5 eksemplari; joon. 8,1 ) ja luust tehtud kitsaid peitleid (8 eksemplari, joon. 8, 2). Võib arvata, et neid riistu on kasutatud mitte niivõrd puu töötlemisel kui just puukoore mahavõtmisel ja sellest esemete valmistamisel. Sarvtalbu on võib-olla tarvitatud ka tapetud loomade nülgimisel ja muudel töödel.

Spetsiaalseteks nahatöötlemisriistadeks on olnud luust naasklid, mida on leitud ligi 40 eksemplari (joon. 8, 6). Nahkade kokkuõmblemiseks kasutatud luunõelu on säilinud aga ainult mõnede katkenditena. Rida luuesemeid näib olevat tarvitatud mitmesugustel punumistöödel: osa puukoorest ja vitstest esemete punumisel, teist osa kalapüügivõrkude valmistamisel (joon. 8,3 ). 


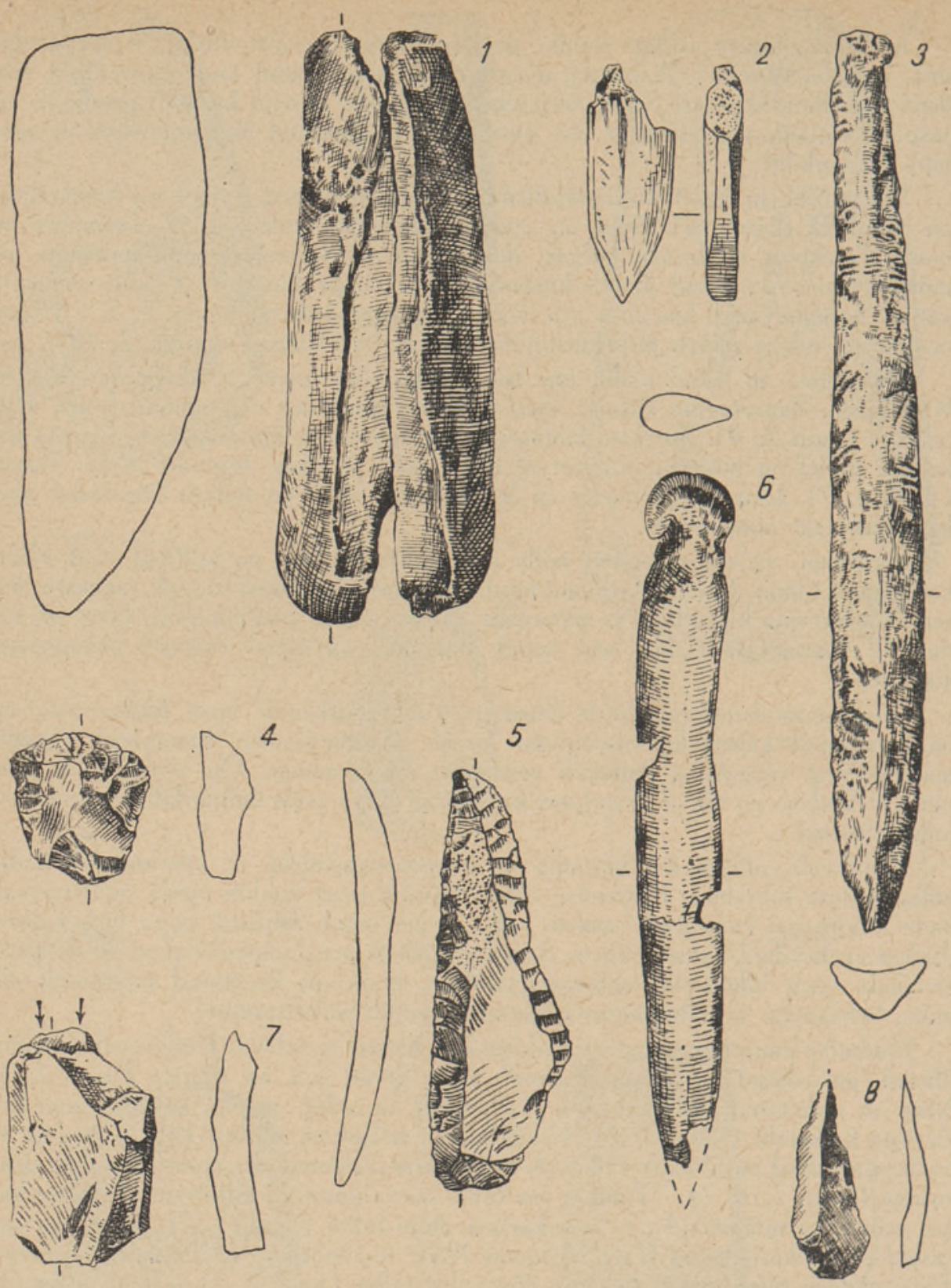

Joon. 8. Sarvest, luust ja tulekivisı tööriistu Akali ja Kullamäe asulatest.

Suhteliselt rohkesti esineb Akali ja Kullamäe asulates väikesi tulekiviesemeid (joon. 8, 4, 5, 7, 8): kõõvitsaid (üle 500 eksemplari), noakesi (umbes 285 eks.), teravikke (umbes 115 eks.) ja uuritsaid (umbes 65 eks.). Neid väikesi riistu on tarvitatud mitmesugustel töödel, peamiselt aga naha, puu ja luu töötlemisel.

Kiviesemete valmistamisel on kasutatud erinevaid võtteid ja vahendeid. Kristallilise kivimaterjali esialgne töötlemine on toimunud tahumise teel löögikivide ja alaskivide abil. Lõplik vorm on esemetele antud lihvimisega. Asulates esineb umbes paarsada lihvimiskivide katkendit. Enamik neist pärineb suurtest maas asetsenud 
lihvimiskividest, mille pealmise pinna vastu on lihvitavat eset hõõrutud kas sõõrikujuliselt või edasi-tagasi. Teine osa lihvimiskive kuulub väikeste nelinurksete tahukivide hulka, mida lihvimisel on hoitud käes.

Tulekivi on töödeldud mitte lihvimise, vaid retuššimise teel. Nagu mainitud, on Akali ja Kullamäe tulekiviesemed kõik võrdlemisi väikesed, olles valmistatud väikeste mõõtmetega tulekivilaastudest. Kuigi asulates leitud laastud ja samuti nende eraldamisel järele jäänud tulekivisüdamikud osutavad, et tulekivi on põhiliselt töödeldud siinsamas, võidi retuššimisel kasutatud survitsaid seni avastada äärmiselt vähe - ainult paar eksemplari.

Peale nimetatud esemete leidub Emajõe suudmeala asulates veel mitmesuguseid muid töö- ja tarberiistu. Nii on siit leitud sarvest ja luust käepidemeid väiksemate

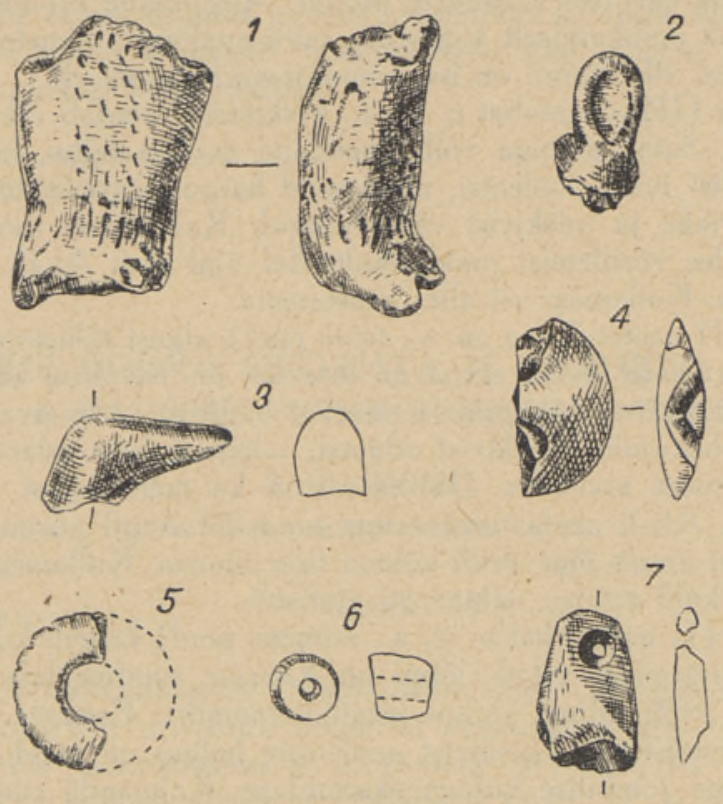

Joon. 9. Savist ja luust skulptururide katkendeid ja merevaikesemeid Akali ja Kullamäe asulatest.

kiviesemete varretamiseks, raske kivivasara poolmik, luuplaadist vööpannal jne. Mõnede munakate suhtes kerkib küsimus, kas neid ei ole kasutatud jahvatuskividena viljaterade peenestamiseks. Mitme eseme otstarve jääb esialgu aga täiesti selgusetuks. Palju on saadud ka väikesi katkendeid, mis ei võimalda enam määrata vastavate esemete kuju ega otstarvet.

Kultuslike esemete hulka kuulub väike arv pisikeste skulptuuride katkendeid ja rohkesti mitmesuguseid ripatseid. Viimaseid on kantud peamiselt kehakatete küljes, kus nad ühtlasi täitsid ehete funktsioone.

Kolm saviskulptuuri kujutavad inimest seisvas asendis (joon. 9, 1). Nad on teostatud äärmiselt skemaatilises laadis. Kuna skulptuurid on nõrgalt põletatud, siis võib oletada, et nad ei olnud mõeldud kestvamaks kasutamiseks. Seevastu merevaigust linnupea (joon. 9, 3) ja luust loomapea katkend (joon. 9, 2) on realistlikud ja valmistatud suure asjatundlikkusega. Nende pinna peen lihv lubab oletada, et neid kujukesi on kasutatud pikemat aega. Mõlema skulptuuride rühma erisugusele tarvitamisviisile viitab ka erinev teostuslaad ja valmistamiseks valitud materjal.

Ripatsite seas on rohkesti merevaigust valmistatud esemeid (joon. 9, 4-7). 58 leitud merevaigutükist on suur osa plaadikujulised, kandmise võimaldamiseks 
läbipuuritud auguga. Merevaigust on tehtud ka rõngaid, v-kujulise auguga nööpe ja toruhelmeid. Mõningad merevaigutükid on töötlemata.

Ripatseid on valmistatud ka õhukestest kivi- ja luuplaadikestest ning eriti loomahammastest, mis kandmise võimaldamiseks on läbi puuritud. Oma suurusega äratab tähelepanu kiltkivirõnga katkend (läbimõõt $12,5 \mathrm{~cm}$ ). Mingiteks kultuslikeks toiminguteks on kasutatud nähtavasti ka värvilisi vôi vee poolt siledaks kulutatud lapergusi kivikesi. Võib-olla tuleb neis näha folkloori kaudu tuntud ,ussikivide“ taolisi maagilisi vahendeid.

Järgnevalt huvitab meid käsitletavate asulate dateerimine. Võttes aluseks materiaalse kultuuri, eriti keraamika arenemise, võib Emajõe suudmeala asustuse jagada viide üksteisele järgnevasse etappi. Viimaste suhteline järjekord on selgesti jälgitav materjali stratigraafiliste leiusuhete põhjal. Absoluutne kronoloogia on esialgu määratav aga ainult umbkaudselt, tuginedes suira-analüüsi andmetele ja naaberalade paralleelidele. Need viis etappi on iseloomustatavad järgmiselt.

Esimest etappi (III aastatuhat e. m. a., keskpaik) esindab Akali asulas kammkeraamika eelaste. Sama etapiga võib ühendada sarvest talbu, koonusekujulisi ja laiu pajulehekujulisi luust nooleotsi, mõningaid harpuuniotsi, mitmeid luust naaskleid, sarvest teravikke ja tulekivist väikeesemeid. Kahtlemata tuntakse kõnesoleva etapi materjale alles võrdlemisi puudulikult. Sel ajal elati Akali asula kõige jõepoolsemas vööndis. Kullamägi oli alles asustamata.

Teise etapi (III aastatuhat e. m. a., teine pool) algust tähistab kammkeraamika ilmumine Akali asulasse. Sellel etapil on tegemist nn. tüüpilise kammkeraamikaga. Lisaks varem mainitud esemetüüpidele tarvitati nüüd ka terav-ovaalse kujuga tulekivist nooleotsi, lehekujulisi tulekivist odaotsi, saledaid luust odaotsi, liitõngi, luust peitleid ja mitut tüüpi kivitalbu. On kasutatud ka merevaigust tehtud ehteid ja väikesi skulptuure. Akali asula territoorium on sellel etapil püsinud peaaegu endisel kohal, nihkudes ainult õige veidi kühmu tipu suunas. Kullamägi asustati kõnesoleva etapi lõpul, kuid esialgu nähtavasti ajutiselt.

Kolmas etapp (II aastatuhat e. m. a., esimene pool) langeb kokku kammkeraamika hilise arengujärguga. Etapi lõpul on Emajõe suudmealale ilmunud varane nöörkeraamika ja veidi hiljem varane tekstiilkeraamika. Esemete vormid on püsinud suurelt osalt endistena. Tulekivist nooleotste hulgas on nüüd hakanud suhteliselt rohkem esinema rombilise kujuga eksemplare. Kolmanda etapiga tuleb ühendada ka lihtsaid silmata kirveid, mis aga kahtlemata pidid olema tuntud juba varemgi. Merevaigust esemete hulk on mõnevõrra veelgi suurenenud. Akali asula territoorium on püsinud peaaegu endisena, näidates vaid teatavat laienemist. Kolmanda etapi kestel on uuesti asustatud ka Kullamägi, kusjuures sealse asula territoorium on nüüd olnud tunduvalt ulatuslikum kui eelmisel etapil.

Neljanda etapi (II aastatuhat e. m. a., teine pool) iseloomulikuks jooneks on kammkeraamika kadumine ja selle asendumine hilisemate keraamikaliikidega hilise nöörkeraamika ja sellega paralleelselt esineva tekstiilkeraamikaga. Mölemad nimetatud keraamikaliigid on sel etapil ühte sulamas ja kujunemas varase metalliaja keraamikaks. Asulate inventaris puuduvad nüüd luuesemed. Tulekivist nooleotstest tarvitatakse endiselt rombilisi vorme, neile lisanduvad kolmnurksed, lantsetikujulised ja nõgusa alusega otsikud. Ilmuvad sirge alusega ja küljenukkidega heiteodaotsad. Kivikirveste hulgas leidub nüüd silmaga eksemplare, kivitalbade hulgas aga nelinurkseid otseteralisi talbu. On tõenäoline, et sellel etapil ilmusid Emajõe suudmealale ka esimesed pronksesemed. Merevaigu vahetus näib seevastu peaaegu täiesti lakkavat. Akali asula territoorium on neljandal etapil nihkunud võrdlemisi järsult jõest kaugemale. Ka Kullamäe asustus on nihkunud kühmu mööda mõnevõrra kõrgemale.

Viienda etapi (I aastatuhat e. m. a., esimene pool) keraamika vastab juba täiesti varasele metalliajale. Selle etapiga ühenduses olevat muud esemelist materjali tuntakse aga alles vähe. Kasutusel on olnud mõned tulekivist nooleotsad, tule- 
kivist kõõvitsad, noakesed ning muud väikeesemed ja üks nelinurkse ristlōikega kivitalvake. Samasse etappi kuuluvad ka mõned kivimunakad, mida on võidud kasutada viljaterade peenestamisel. Luuesemeid ei ole säilinud. Kiviesemete hulga kahanemine, mis väiksemas ulatuses on märgatav juba eelmisel etapil, on võib-olla ühenduses metallriistade tarvituselevõtmisega. Asustus nii Akalis kui ka Kullamäel on jätkuvalt nihkunud kühmude kõrgematele osadele.

Emajõe suudmeala asulate materjal omab rohkesti paralleele teistes sama aja asulates naaberaladel, peamiselt Eesti NSV ja Läti NSV territooriumil. See asjaolu näitab, et materiaalse kultuuri arenemine on neil aladel kulgenud üldiselt ühesugustes tingimustes ja ühesuguseid teid mööda. Kuigi võib märgata ka mõningaid kohalikke erijooni, mis avalduvad eriti hilisematel etappidel, on Emajõe suudmeala asustuse kronoloogiline skeem üldistes joontes rakendatav ka teiste neoliitiliste ja varase metalliaja asulate suhtes lähematel naaberaladel. See asjaolu omab edaspidiste uurimistööde teostamisel suurt tähtsust. Eesti NSV Teaduste Akadeemia
Ajaloo Instituut
Saabus toimetusse 22. IV 1954

\title{
ПОСЕЛЕНИЯ ЭПОХИ НЕОАИТА И РАННЕГО МЕТАЛАА В РАЙОНЕ УСТЬЯ РЕКИ ЭМАЙЫГИ
}

\author{
Л. Ю. Янитс, \\ кандидат исторических наук
}

Резюме

В статье рассматривается археологический материал из поселений Акали и Кулламяги и делается попытка установить его хронологию.

Оба поселения расположены в восточной Эстонии, на западном берегу Чудского озера, в районе устья р. Эмайыги (рис. 1), и охватывают сравнительно большую территорию - Акали примерно 17000 м² $^{2}$ (рис. 2), Кулламяги около 10000 м² $^{2}$ (рис. 3). Однако ни в Акали, ни в Кулламяги вся площадь поселения в целом не использовалась одновременно. Вначале поселения располагались вблизи реки. Позже, по мере повышения уровня воды и затопления берегов, поселения стали отодвигаться дальше от реки, на более возвышенные места. Так как оба поселения существовали в течение очень длительного времени, то перемещение их местоположений дает возможность выделить комплексы вещей, относящиеся к различным периодам существования поселений, что имеет большое значение для установления хронологии.

В инвентаре обоих поселений по численности первое место занимает керамика (в Акали обнаружено почти 27000, а в Кулламяги свыше 5000 черепков). Каменных предметов найдено, соответственно, 1500 и около 300. Изделий из кости и рога найдено всего 280, кусков янтаря и янтарных изделий - 58. Эти предметы происходят по преимуществу из Акали.

Наиболее твердую основу для установления относитедьной хронологии наших стоянок дает керамика, которая подвергалась изменениям значительно быстрее, чем остальные орудия труда и быта. На основании стратиграфии залегания разных типов керамики устанавливается их хронологическая последовательность.

Древнейшая керамика весьма примитивна и имеет орнамент, характер которого еще не вполне определился (рис. 4:1-3). Эта керамика обна- 
ружена только на поселении Акали, где она бытовала до появления ямочно-гребенчатой керамики.

В развитии ямочно-гребенчатой керамики прослеживаются в основном два этапа. Более раннему этапу соответствует типичная ямочно-гребенчатая керамика (рис. 4:4-6). Она характеризуется зональностью орнаментаџии, в которую нередко входят геометрические мотивы. Типичная ямочно-гребенчатая керамика наряду с более поздними типами керамики встречается уже и в Кулламяги.

У поздней ямочно-гребенчатой керамики орнамент становится более редким, выполнение его - небрежным. Зональная структура его начинает разлагаться (рис. 4:7-10). Входят в обиход сосуды со штрихованной поверхностью.

Под конец периода бытования поздней ямочно-гребенчатой керамики в поселениях района устья Эмайыги появляется шнуровая керамика (рис. $5: 1,2)$. Она отличается резко от обычной для более раннего времени керамики поселений, но имеет большое сходство со шнуровой керамикой, встречаемой. в могильниках культуры боевых топоров. Ранняя шнуровая керамика обнаружена в Акали и Кулламяги только в виде единичных Фрагментов. Примерно к этому же времени относится появление текстильной керамики (рис. 5:3).

После выхода из употребления ямочно-гребенчатой керамики обитатели поселений перешли к массовому изготовлению поздней шнуровой, а также текстильной керамики (рис. 5:4-6). В результате дальнейшего развития в последний период существования поселений здесь возникла керамика периода раннего металла (рис. 5:7-10), очень сходная с керамикой, находимой в древнейших укрепленных поселениях и в могильниках с каменными ящиками.

Остальной инвентарь поселений Акали и Кулламяги довольно обычен. Он содержит наконечники стрел, дротиков и гарпунов, топоры и долота, шилья, скребки, ножички, сверла, резџы, точильные камни и пр. (рис. 68). В числе предметов, связанных с культом, можно отметить фрагменты фигурок людей, животных и птиџ и различные привески из янтаря, кости и камня (рис. 9).

На основании развития материальной культуры, главным образом керамики, весь период существования древних поселений в районе устья Әмайыги можно разделить на пять последовательных этапов. Абсолютную хронологию можно установить пока только приблизительно. Первому этапу (середина III тысячелетия до н. э.) соответствует древнейшая, примитивная керамика; второму этапу (вторая половина III тысячелетия до н. э.) - типичная ямочно-гребенчатая керамика; третьему этапу (первая половина II тысячелетия до н. ә.) - поздняя ямочно-гребенчатая керамика; четвертому этапу (вторая половина II тысячелетия до н. э.) поздняя шнуровая и текстильная керамика; пятому этапу (первая половина I тысячелетия до н. э.) - керамика раннего металла.

Так как материал из поселений района устья Эмайыги имеет много аналогий в материалах других памятников того же времени, особенно на территории Эстонской и Латвийской ССР, то установленная выше хронологическая схема в общих чертах может найти более широкое применение. 